Note

\title{
Dimerization and Oligomerization of Ethylene Catalyzed by a Palladium(II) Complex with Imine-phosphine Ligand
}

\author{
Jwu-Ting Chen* \\ ), Shiuh-Tzung Liu* ( \\ ) and Ke-Qing Zhao ( \\ Department of Chemistry, National Taiwan University, Taipei, Taiwan 106, R.O.C.
}

The palladium-iminophosphine complex $\left[\mathrm{Pd}(\mathrm{P}-\mathrm{N})\left(\mathrm{CH}_{3}\right) \mathrm{Cl}\right](\mathrm{P}-\mathrm{N}=o$-diphenyl-phosphino- $N$-benzaldimine $)$ has been found to be a catalyst for dimerization and trimerization of ethylene. Some mechanistic insight concerning this oligomerization is discussed.

\section{INTRODUCTION}

Transition-metal catalyzed dimerization and oligomerization of ethylene or propylene are well documented. ${ }^{1}$ Among the known cases, palladium complexes are generally less used presumably due to their relatively low reactivity. However, palladium chloride has been known to be a catalyst for dimerization of ethylene in various solvents. ${ }^{2}$ In a kinetic study, Brookhart and coworkers suggested that the activation energy of the ethylene insertion into a $\mathrm{Pd}-\mathrm{C}$ bond of $[(\mathrm{N}-\mathrm{N}) \mathrm{PdR}]^{+}$is ca. $19 \mathrm{kcal} / \mathrm{mol}$, which may be easily accessed under mild conditions. ${ }^{3}$ Indeed, dimerization of ethylene catalyzed by $\left(\mathrm{C}_{6} \mathrm{H}_{5} \mathrm{CN}\right)_{2} \mathrm{PdCl}_{2}$ and $\left[\left(\eta^{3} \text {-allyl }\right) \mathrm{Pd}(\mathrm{P}-\mathrm{O})\right]^{+}$has been reported recently. ${ }^{4,5}$ This outcome indicates the importance of ligand effect.

Recently, ligands of mixed donors of phosphorus and nitrogen have received much attention; particularly those with imino donor are thought to have strong trans-influence. ${ }^{5}$ Such complexes can lead to stoichiometric olefin and $\mathrm{CO}$ insertion. To understand the ligand effect in alkene oligomerization, we report the results of $\left[\mathrm{Pd}(\mathrm{P}-\mathrm{N})\left(\mathrm{CH}_{3}\right) \mathrm{Cl}\right][\mathrm{P}-\mathrm{N}$ : phosphino-imino ligand] catalyzed dimerization of ethylene.

\section{RESULTS AND DISCUSSION}

The imine-phosphine palladium complex $[\mathrm{Pd}(\mathrm{P}-\mathrm{N})-$ $\left.\left(\mathrm{CH}_{3}\right) \mathrm{Cl}\right] \mathbf{1}(\mathrm{P}-\mathrm{N}=o \text {-diphenylphosphino- } N \text {-benzaldimine })^{6}$ does not help the reactions of ethylene polymerization, but is an excellent catalyst for dimerization of ethylene. In the typical run, in a $600 \mathrm{~mL}$ autoclave was placed complex $1(0.02$ mmol) as well as sodium tetrakis[3,5-di(trifluoromethyl)phenyl]borate $(0.02 \mathrm{mmol})$ in dichloromethane $(50 \mathrm{~mL})$ and then pressured with ethylene. During the reaction course, ethylene was refilled when the pressure was found to drop. After the pressure stopped changing, the reaction products were distilled and trapped at $-78{ }^{\circ} \mathrm{C}$. The analysis was done by ${ }^{1} \mathrm{H}$ NMR spectroscopy. The results of the oligomerization of ethylene are summarized in Table 1.

In all instances, only 1-butene and 1-hexene were produced. It is worth nothing that the formation of any other isomeric species (e.g., 2-butene) or longer carbon chain alkenes was not observed. When the reactions were carried out under higher pressure (entries 1-3), the relative yields of 1-hexene versus 1-butene increase along with the decrease of overall conversion. As to the solvent effect, a greater selection for 1-butene over 1-hexene is observed in aromatic solvents than in dichloromethane, although the overall conversions are still worse. The same is true of higher temperatures.

We deliberately examined the reaction of mixing 1butene and ethylene as the starting material, but only 1-butene was recovered. There was no observation of any product of co-dimerization or dimerization of 1-butene. While 1-butene was employed as the sole reactant, isomerization was found to take place, resulting in the formation of 2-butenes.

In constrast to the diimine-palladium complexes which are known to catalyze the polymerization of various olefins, the imine-phosphine complex developed in this study is suitable for oligomerization of ethylene. A possible reaction pathway is proposed in Scheme I. The sodium tetraarylborate would generate a species I with unsaturated coordination at the palladium(II) center. Ethylene-insertion followed by $\beta$-elimination could result in the unsaturated complex of metal hydride II which is believed to be responsible for the dimerization and trimerization of ethylene.

Two aspects concerning the catalytic activity on the imine-phosphino complex of palladium(II) are noteworthy. First of all, although the complex is able to catalyze the isomerization of 1-butene to 2-butene, this process has not been found in the dimerization process. Secondly, the forma-

This article is dedicated to the late Professor Ta-shue Chou of the Institute of Chemistry, Academia Sinica. 
Table 1. Oligomerization of Ethylene Catalyzed by $\mathrm{Pd}(\mathbf{P}-\mathbf{N}) \mathrm{MeCl}$

\begin{tabular}{|c|c|c|c|c|c|}
\hline $\begin{array}{c}\text { Pressure of } \\
\mathrm{CH}_{2}=\mathrm{CH}_{2} \text { ( psi) }\end{array}$ & solvent & $\mathrm{T}\left({ }^{\circ} \mathrm{C}\right)$ & $\begin{array}{l}\text { Time } \\
\text { (h) }\end{array}$ & Product & $\begin{array}{c}\text { Turnover no. } \\
\text { x } 10^{3} \text {. }\end{array}$ \\
\hline \multirow[t]{2}{*}{80} & \multirow[t]{2}{*}{$\mathrm{CH}_{2} \mathrm{Cl}_{2}$} & \multirow[t]{2}{*}{$\mathrm{rt}$} & \multirow[t]{2}{*}{72} & butene $(0.928 \mathrm{~mol})$; & 46.4 \\
\hline & & & & 1-hexene $(0.266 \mathrm{~mol})$ & 13.6 \\
\hline \multirow[t]{2}{*}{200} & \multirow[t]{2}{*}{$\mathrm{CH}_{2} \mathrm{Cl}_{2}$} & \multirow[t]{2}{*}{$\mathrm{rt}$} & \multirow[t]{2}{*}{12} & 1-butene $(0.176 \mathrm{~mol})$; & 8.80 \\
\hline & & & & 1-hexene $(0.049 \mathrm{~mol})$ & 2.45 \\
\hline \multirow[t]{2}{*}{400} & \multirow[t]{2}{*}{$\mathrm{CH}_{2} \mathrm{Cl}_{2}$} & \multirow[t]{2}{*}{$\mathrm{rt}$} & \multirow[t]{2}{*}{12} & 1-butene $(0.125 \mathrm{~mol})$; & 6.30 \\
\hline & & & & 1-hexene $(0.025 \mathrm{~mol})$ & 1.30 \\
\hline \multirow[t]{2}{*}{80} & \multirow[t]{2}{*}{$\mathrm{C}_{6} \mathrm{H}_{6}$} & \multirow[t]{2}{*}{$\mathrm{rt}$} & \multirow[t]{2}{*}{72} & 1-butene $(0.649 \mathrm{~mol})$; & 32.5 \\
\hline & & & & 1-hexene $(0.137 \mathrm{~mol})$ & 6.85 \\
\hline \multirow[t]{2}{*}{80} & \multirow[t]{2}{*}{$\mathrm{CH}_{2} \mathrm{Cl}_{2}$} & \multirow[t]{2}{*}{$60^{\circ} \mathrm{C}$} & \multirow[t]{2}{*}{48} & 1-butene $(0.103 \mathrm{~mol})$; & 5.20 \\
\hline & & & & 1-hexene $(0.02 \mathrm{~mol})$ & 1.0 \\
\hline \multirow[t]{2}{*}{400} & \multirow[t]{2}{*}{$\mathrm{C}_{6} \mathrm{H}_{6}$} & \multirow[t]{2}{*}{$\mathrm{rt}$} & \multirow[t]{2}{*}{48} & 1-butene $(0.155 \mathrm{~mol})$; & 7.8 \\
\hline & & & & 1-hexene $(0.016 \mathrm{~mol})$ & 0.8 \\
\hline \multirow[t]{2}{*}{80} & \multirow[t]{2}{*}{$\mathrm{C}_{6} \mathrm{H}_{5} \mathrm{CH}_{3}$} & \multirow[t]{2}{*}{$\mathrm{rt}$} & \multirow[t]{2}{*}{72} & 1-butene $(0.183 \mathrm{~mol})$; & 9.2 \\
\hline & & & & 1-hexene $(0.029 \mathrm{~mol})$ & 1.5 \\
\hline
\end{tabular}

Experimental Procedure: Into an autoclave $(600 \mathrm{~mL})$ was placed $\mathrm{Pd}(\mathbf{P}-\mathbf{N}) \mathrm{MeCl}(0.02 \mathrm{mmol})$ and $\mathrm{NaBAr}_{4}\left(\mathrm{Ar}=3,5-\left(\mathrm{CF}_{3}\right)_{2} \mathrm{C}_{6} \mathrm{H}_{3}\right)(0.02 \mathrm{mmol})$ in dried solvent. Ethylene gas was pressured. The mixture was stirred for a period of time and the reaction products were analyzed spectroscopically.

Scheme I Reaction pathway for oligomerization

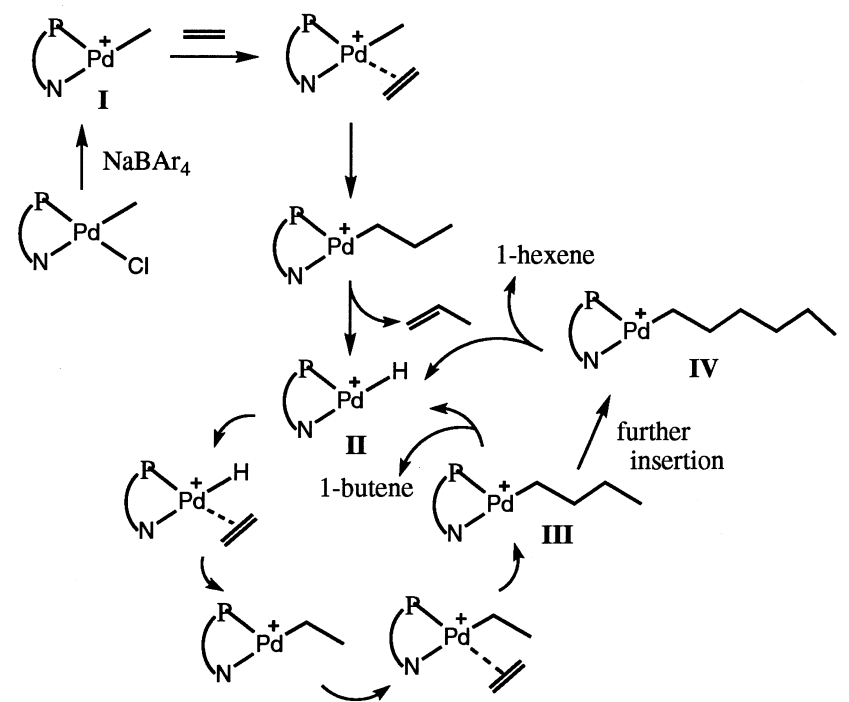

tion of higher olefins beyond 1-butene was lacking. It indicates that either the coordination of ethylene is probably overwhelming other $\alpha$-olefins or insertion of a high olefin is slow in such a system.

\section{EXPERIMENTAL SECTION}

\section{General Information}

Nuclear magnetic resonance spectra were recorded in
$\mathrm{CDCl}_{3}$ on either a Bruker AC-E 200 or AM-300 spectrometer. All of the reaction, manipulation, and purification steps were performed under a dry nitrogen atmosphere. Tetrahydrofuran was distilled under nitrogen from sodium benzophenone ketyl. All chemicals and solvents were used from commercial sources without further purification. $\mathrm{Pd}(\mathbf{P}-\mathbf{N}) \mathrm{MeCl}$ was prepared according to the procedure previously reported. ${ }^{6}$

\section{Procedure for Dimerization}

Into an autoclave $(600 \mathrm{~mL})$ was placed $\mathrm{Pd}(\mathbf{P}-\mathbf{N}) \mathrm{MeCl}$ $(0.02 \mathrm{mmol})$ and $\mathrm{NaBAr}_{4}\left(\mathrm{Ar}=3,5-\left(\mathrm{CF}_{3}\right)_{2} \mathrm{C}_{6} \mathrm{H}_{3}\right)(0.02 \mathrm{mmol})$ in dried solvent. Upon flash with ethylene gas several times, ethylene gas was loaded. During the reaction, ethylene was refilled when the pressure was found to drop. The mixture was stirred for a period of time and the reaction products were analyzed spectroscopically.

\section{ACKNOWLEDGMENT}

We thank the Chinese Petroleum Cooperation (NSC88CPC-M002-05) for financial support.

Received December 15, 1999.

\section{Key Words}

Ethylene; Dimerization; Palladium; Iminephosphine. 


\section{REFERENCES}

1. Pillai, S. M.; Ravindranathan, M.; Sivaram, S. Chem. Rev. 1986, 86, 353.

2. Kusunoki, Y.; Katsuno, R.; Hasegawa, N.; Kurematsu, S.; Nago, Y.; Ishii, K.; Tsutsumi, J. Bull. Chem. Soc. Jpn. 1966, 39, 2021.

3. Barlow, M. G.; Bryant, M. J. Haszeldine, R. N.; Mackie, A. G. J. Organomet. Chem. 1970, 21, 215.

4. Mecking, S.; Keim, W. Organometallics 1996, 15, 2650.

5. (a) Sperrle, M.; Aeby, A.; Consiglio, G.; Pfaltz, A. Helv.
Chim. Acta 1996, 79, 1387. (b) Sperrle, M.; Consiglio, G. Chem. Ber. 1997, 130, 1557, and references therein. (c) van den Beuken, E. K.; Smeets, W. J. J.; Spek, A. L.; Feringa, B. L. J. Chem. Soc., Chem. Commun. 1998, 223. (d) Shirakawa, E.; Yoshida, H.; Takaya, H. Tetrahedron Lett. 1997, 38, 3759. (e) Shirakawa, E.; Yoshida, H.; Kurahashi, T.; Nakao, Y.; Hiyama, T. J. Am. Chem. Soc. 1998, 120, 2975.

6. Reddy, K. R.; Chen, C.-L.; Liu, Y.-H.; Peng, S.-M.; Chen, J.-T.; Liu, S.-T. Organometallics 1999, 18, 2574. 